\title{
Religious exemption, justice, and territories around the year 1000: the forgeries of Worms
}

\author{
Thomas Kohl*
}

While immunities were perhaps the most important form of religious exemption in the medieval West throughout the Middle Ages, they have not been studied extensively for the period around the turn of the millennium. This paper treats immunities from the perspective of the institutions that received them, drawing on the example of the bishops of Worms in southwestern Germany. Two questions are asked: 1) What did institutions expect from receiving immunities? 2) Can we tell if they had consequences in practice? The unique sources from Worms - a dossier of forged or interpolated royal charters created by Bishop Hildibald of Worms (978-998), and numerous documents connected to his successor Burchard (10001025) - make it possible to study these questions in depth. Hildibald's charters were one important starting point in the redrawing of regional power structures in favour of the church of Worms and thus its developing territorial lordship. In part, they expanded property and immunity rights, but Hildibald's forgeries were mostly concerned with specifying and defining the terms of immunity that his church already possessed in face of regional competition by the monastery of Lorsch and by the Salian dukes and counts. This suggests that practical advantages in terms of income and power were what made immunities interesting for a church. Hildibald's successor Burchard used his close ties to Emperor Henry II to achieve a large degree of independence from these regional political powers, relying in part on Hildibald's forged charters. As a result of this, the counts' powers in and around Worms were all but abolished, and judicial matters lay in the hand of the bishop. These changes in the regional power structure were accompanied by outbreaks of violence, which were countered by the emperor's intervention and the promulgation of new laws by the bishop.

Keywords: immunities; Worms; justice; Burchard of Worms; Hildibald of Worms; charters; forgeries

\section{Introduction}

In spite of centuries of legal history and decades of cultural history, and in spite of numerous studies on the subject, historians are still troubled by the judicial privileges held by religious communities in the Latin West that are generally known as simmunities $; ;^{1}$ it still remains a challenge to understand in which way immunities and political entities - such as realms, principalities or states - coexisted. How did the dialectic between a (supposed) normal political order and the spaces exempt from it - but at the same dependent on a ruler who was the head of the very political entity from which the immunity granted exemption - function?

* Correspondence details: Thomas Kohl, Eberhard-Karls-Universität Tübingen, Seminar für mittelalterliche Geschichte, Wilhelmstraße 36, 72074 Tübingen. Email: Thomas.kohl@uni-tuebingen.de.

1 Rosenwein, Negotiating Space; Murray, Immunity, Nobility and the Edict of Paris; Bachrach, Immunities as Tools; see for a recent survey starting from Rosenwein's work Bührer-Thierry and Jégou, Construction des pouvoirs. 
Our problems are in part due to our modern preoccupation with the nation-state as the sole important form of political order, symbolized to no small degree by a monopoly on violence and an all-encompassing exercise of justice. Both are of course largely theoretical ideas, but they are nevertheless hard to square with the concept of exempt spaces within political entities. While recent developments may seem to indicate a resurgence of the nation state in Europe and elsewhere - they certainly indicate a resurgence of nationalism - there are signs that nation states in their nineteenth- and twentieth-century form have lost their inevitability: The ever increasing number across the world of failed states or of states with weak statehood is a very clear indicator that political entities may take on other forms than a nation state or its medieval precursors.

None of this is, of course, very surprising to researchers studying premodern or nonwestern societies who have known all along that there are more types of political order than states in their nineteenth- and twentieth-century incarnation. Still, medievalists have for the most part tended to see immunities in respect to a central power, usually embodied in kings. Was the granting of immunities a sign of weak central power, or was it conversely a sign of active and energetic royal power? Did kings unwittingly or negligently weaken their own political institutions by conferring them, or did they strengthen them by creating or supporting special, sacred places (or by securing military support by the privileged institutions)? These questions have been with us for a long time, and been discussed by generations of scholars, and they will remain important in the future. ${ }^{2}$

On the following pages, however, I am going to look at immunities not from the perspective of those who received them, nor those who dispensed them. This leads to two questions: What did institutions expect to gain from receiving immunities? And: can we tell whether they had consequences in practice?

The first question seems deceptively easy to answer. To begin, Barbara Rosenwein and others have convincingly demonstrated that receiving an immunity marked out the holder as special, and, when applied to a church as was most often the case, it was thus marked as a holy and privileged place. The second, more traditional line of reasoning is of an overtly practical nature: Excluding public judges and other officials from the spaces and people owned by a church meant more income from dues of a different nature that were then redirected toward the institution and control of jurisdiction over them, which could be a step in the creation of a territorial ecclesiastical principality. I believe that both of these reasons mattered.

Answering the first question - what churches expected or hoped to gain from immunities - may be best studied by looking at examples in which representatives of an institution took it into their own hands to create or expand an immunity, by resorting to forgery or interpolation. As for answering the second question regarding the consequences of immunities in practice, that requires a special kind of evidence concerning the application of the rights gained in those privileges. One of the churches for which we have both types of evidence is the episcopal church of Worms located on the River Rhine about $50 \mathrm{~km}$ south of Mainz, and which will therefore form the basis of what follows.

2 The idea presented by Barbara Rosenwein, Alexander Murray and others that granting immunities may have positive effects on royal power is not as new as one might think: Already in 1928 the second edition of Heinrich Brunner's Deutsche Rechtsgeschichte argued that immunities were granted from a position of strength and did not weaken the Carolingian political order (400). 


\section{The church of Worms around the millennium}

In regard to the themes of this special issue and also in respect to law, its application and the development of an ecclesiastical lordship, Worms is an extremely interesting case because of several unique sets of documents transmitted from there. Some of these were written by or are at least connected to its best known and most brilliant bishop, Burchard (1000-1025). ${ }^{3}$ Burchard is best known for his Decretum, a collection of canon law consisting of twenty volumes that became authoritative for at least a century before it was superseded by Gratian's Decretum. ${ }^{4}$ However, Burchard is also credited with strengthening the position of his church in its diocese and its see, which, according to the Vita Burchardi, written shortly after his death in about 1030, had been nearly destroyed and deserted because of conflicts between the church of Worms and Duke Otto, whose grandson Conrad would eventually become king in $1024 .{ }^{5}$ This conflict was solved with the aid of Emperor Henry II (1002-1024), who owed his election in part to Bishop Burchard, as was a major dispute with the nearby abbey of Lorsch. ${ }^{6}$ It was in the context of these conflicts that Burchard issued his second, much shorter legal text, the so-called Lex familiae Wormatiensis ecclesiae, well-known because it is the earliest example of a law (lex) issued for the familia of a church, that is, the dependants of the church of Worms. ${ }^{7}$ The text is also important to urban historians such as Knut Schulz, because it contains some of the earliest clauses specifically directed at the inhabitants of an episcopal city, regardless of their legal status, thus foreshadowing the emergence of citizens as a legally distinct group. ${ }^{8}$

Without belittling Burchard's accomplishments, the focus of this article is however on one of Burchard's predecessors, Bishop Hildibald (978-998), who in many ways laid the foundation for Burchard's success. Hildibald died in 998, that is two years before Burchard's election, and there were no fewer than three bishops in between, among them Burchard's older brother Franco (998-999), but none of them lived long enough to have an impact. ${ }^{9}$

Bishop Hildibald's efforts as documented in charters - some authentic, many forged show that immunities were a central concern to him. In creating or procuring these documents for the church of Worms, Hildibald put to use his ties to the courts of Emperor Otto II, Empress Theophanu and Otto III, and also profited from his intimate knowledge of the emperors' administration: indeed, Hildibald himself was the head of the imperial administration: he was named chancellor in 977 and continued to act as chancellor after he had been elected as bishop of Worms. ${ }^{10}$ Hildibald was therefore uniquely placed to obtain (or create) privileges for himself and for his church, with or without the king's approval.

See on Burchard Austin, Shaping Church Law, and the contributions in Hartmann, Bischof Burchard von Worms. For the history of Worms in this period, see Kohl and Felten, Worms; Bönnen, Blütezeit des hohen Mittelalters; Zotz, Bischöfliche Herrschaft.

5 See on Burchard's Vita Haarländer, Vita Burchardi, and Bachrach, Histories of a Medieval German City, 29-60 for a useful English translation and commentary. On the history of the Salian family, cf. Weinfurter, Jahrhundert der Salier.

6 See below, p. 225-226.

7 Burchard of Worms, Lex familiae Wormatiensis ecclesiae, ed. Weiland, 640-644.

8 Schulz, Denn sie lieben die Freiheit so sehr; idem, Wormser Hofrecht.

9 Kohl and Felten, Worms, 126.

10 Hildibald was the first chancellor to retain his office at the court after he became a bishop. 
Before moving on to examine Hildibald's charters, it is necessary to outline the problems that the episcopal church of Worms faced around the turn of the millennium. The first problem was its small size, which limited the resources available to its bishops. The medieval diocese of Worms consisted of little more than a sickle-shaped area around Worms around the lower Neckar River and the Kaiserslautern Basin west of the Rhine up to Landstuhl (Fig. 1). This makes it one of the smallest bishoprics in the German part of the Ottonian Empire.

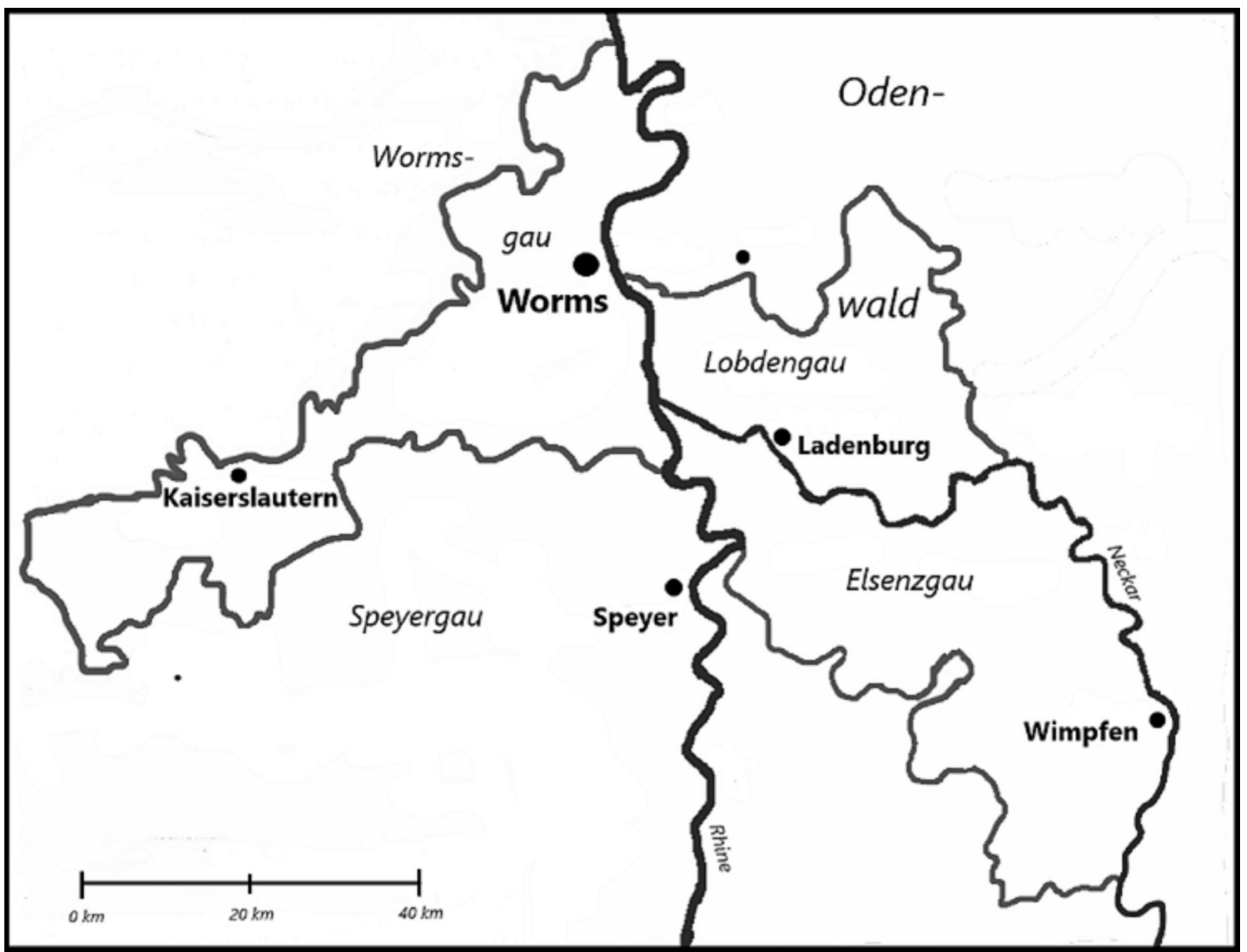

On top of this, there were no important monasteries or chapters within the boundaries of the diocese - this in contrast to all of the neighbouring dioceses, which were home to important institutions such as Hornbach (diocese of Metz), Weißenburg and Klingenmünster (Speyer), Mosbach, Amorbach and Fulda (Würzburg) and, above all, Lorsch, in the archdiocese of Mainz, situated just across the Rhine only a few kilometres east of Worms.

The second problem Worms faced related to competition: other political and ecclesiastical influences were strong in Worms. The monastery of Lorsch owned important assets in the city and the diocese of Worms, and in the early eleventh century tensions between the monastery and the episcopal church ran so high that Emperor Henry II was forced to intervene in 1012 to restore peace. ${ }^{11}$ Even more important was the presence of a dominant lay power within the city walls; this was quite unusual in the eastern kingdom, in contrast to western Francia, where powerful dukes and counts controlled most cities. In Worms, however, the 
counts and dukes from the future royal family known to historians as the Salians owned a castle - possibly a successor to Charlemagne's palace. Since probably the late ninth century, this family had held an increasing number of counties in the Rhein-Main-Neckar area, first in Worms, then also in Speyer and in the Nahegau. ${ }^{12}$ Konrad the Red, who died in the battle of the Lechfeld in 955, and his son, Otto of Worms, were named dukes of Lotharingia and Carinthia respectively, although both eventually lost their duchies - though in Otto's case the loss was compensated in part by property taken from the monastery of Weißenburg and the episcopal church of Worms. ${ }^{13}$ This was certainly one of the reasons for the tension between the bishops and the Salians. One of Duke Otto's sons was Brun, later Pope Gregory V; Otto's grandson Konrad was elected king in 1024. In short, this was one of the most highranking and powerful families in the empire, and its home and most important power base was Worms.

\section{Creating, delineating and specifying immunity: Bishop Hildibald's forgeries}

It is in the face of this background of local competition for power and resources that we must understand Bishop Hildibald's forgeries. Far-reaching rights of immunity for his church were a way of taking on both the monastery of Lorsch - which itself had enjoyed royal protection and immunity rights since Charlemagne - and the Salian dukes, whose power was based on public rights stemming from the counties they held, and from which immunities granted exemption. Alongside this, property rights and public dues themselves were further fields of contention that Hildibald treated in his forgeries.

What were the specific rights that Hildibald - working together with an anonymous notary known as $\mathrm{HB}$ - tried to obtain for his church through forging documents? Johann Lechner, who first studied these charters extensively, ${ }^{14}$ identified three regional groups. One concerned the city of Worms; the second one the regions of the Lobdengau and the Odenwald; and the third the area around Wimpfen at the southwestern end of the diocese; but in fact all of these concerns are intertwined in the forged charters (Fig. 1). ${ }^{15}$

The starting point is a forged charter attributed to the long-dead Frankish king Dagobert I, and dated to $628 .{ }^{16}$ It contains a grant to Worms of all royal property and most royal rights except comitatu and stipe - that is high justice and certain dues - in the Lobdengau, and forest rights in the part of the Odenwald, a mountain range east of the Rhine that belonged to the Lobdengau, that is, exactly in those areas in which Lorsch also held extensive rights. The donation supposedly made by King Dagobert also included a palace in Ladenburg, which probably never existed, but of course supported the notion that everything important in Ladenburg, the centre of the Lobdengau, and the entire Lobdengau itself rightfully belonged to

12 Other counts mentioned here since the mid-tenth century are assumed to have been subordinated to the Salian dukes and counts (Zotz, Adelsherrschaften am Mittelrhein um 1000, 354).

13 Zotz, Adelsherrschaften am Mittelrhein um 1000, 361-362.

14 Lechner, Die älteren Königsurkunden, 364-401.

15 The charters forged or interpolated by Hildibald are: Die Urkunden der Merowinger 1, 30, ed. Kölzer, 81-84; Die Urkunden Pippins 20, ed. Mühlbacher, 28-29; Die Urkunden Karl des Großen 257, ed. Mühlbacher, 371-372; Die Urkunden Ludwigs des Frommen 25 and 282, ed. Kölzer, 65-68 and 702-704; Die Urkunden Ludwigs des Deutschen 74a, 74b, 179 ed. Kehr, 105-108, 257-258; Die Urkunden Arnolfs 166 and 192 ed. Kehr, 253-254 and 296-298; Die Urkunden Ottos I. 392, ed. Sickel, 533-535; Die Urkunden Ottos II. 46, ed. Sickel, 55-56.

16 Die Urkunden der Merowinger 1, 30, ed. Kölzer, 81-84. 
the bishop of Worms. Hildibald's forgery even goes beyond that. In falsely claiming that the Lobdengau extended all the way east to the River Itter, the forger expanded the Lobdengau by several miles and thus added to the rights of the church of Worms. ${ }^{17}$ King Dagobert's charter also contains an immunity clause for all property belonging to the church of Worms, but also to all villas, properties and monasteries belonging to the city (civitas). ${ }^{18}$

Forged charters attributed to the kings and emperors Pippin, Charlemagne, Louis the Pious and Louis the German, Arnulf, and Otto I confirmed and expanded these rights, adding donations, and expanding the immunity by denying the count's rights in all matters that concerned the familia of Worms - which had been explicitly reserved in the Dagobert charter. They also include reasons for - supposedly - renewing the privileges: alleged attempts by agents of the fisc to reclaim rights in the Lobdengau in the case of Charlemagne and Louis the German, and - quite truthfully - a conflict with Lorsch in the charter issued in the name of Otto I. ${ }^{19}$ This charter is one of only two among those forged under Hildibald to be preserved in its original form. ${ }^{20}$ The direct use of phrases drawn from authentic charters show that the charters are somewhere in between interpolations and outright forgeries. Bishop Hildibald and his notary HB were very well informed: they named the correct abbots and bishops for the time a grant was supposedly issued (although Bishop Amandus who is mentioned in the Dagobert charter is not known otherwise), and seem to have known other historical circumstances quite well.

Which other rights did Hildibald's forgeries claim? Toll-taking from the familia of the church of Worms was banned, first in an interpolated charter of Pippin. ${ }^{21}$ In another interpolation, Hildibald expanded an early- to mid-tenth century forgery supposedly issued by Emperors Louis the Pious and Lothar giving the tolls of the merchants, craftsmen and Frisians

17 Huffschmid, Ostgrenze des Lobdengaues im Odenwalde. See on Ladenburg and Worms Bönnen, Bistum und das Hochstift Worms, 17-19; Bönnen, Bistum und das Hochstift Worms. The monastery of Lorsch did not accepted the extension of the Lobdengau, and countered Worms's claim in kind with a hugely inflated border description of the marca of Heppenheim (on the foot of the Odenwald), which had been given to Lorsch by Charlemagne (Codex Laureshamensis 1, 6a, ed. Glöckner, 282-278).

18 Interestingly the scribe of a cartulary in the twelfth-century cartulary in which most of the royal charters from Worms are preserved changed emunitas to communitas, which makes no sense, but which might perhaps be a clumsy attempt at addressing a more pressing concern of his time: the commune of Worms, which threatened the bishop's position in his own town (see for Worms in the twelfth century Bönnen, Blütezeit des hohen Mittelalters, and Zotz, Bischöfliche Herrschaft).

19 Die Urkunden Karls des Großen 257, ed. Mühlbacher, 371-372; Die Urkunden Ludwigs des Deutschen 74ab, ed. Kehr, 105-108; Die Urkunden Ottos I. 392, ed. Sickel, 533-535.

20 The other is Die Urkunden Ottos II. 46, ed. Sickel, 55-56.

21 Die Urkunden Pippins 20, ed. Mühlbacher, 28-29. 
travelling to market in Worms to the episcopal church. Hildibald expanded this ruling with an interpolation to include the pre-urban settlements of Wimpfen and Ladenburg. ${ }^{22}$ Eventually, through a forged charter of King Louis the German, Hildibald also claimed the mint and the modium regis, a grain tax owed by the inhabitants of the city for his church. ${ }^{23}$

In regard to Wimpfen and the small collegiate church there that formed the nucleus of the Worms property in the Wimpfen area, and which make up the third important topic of the forgeries, it is interesting to note that the forger's issue here was not ownership, which was important in the forgeries about Ladenburg. Wimpfen apparently belonged securely to the church of Worms. Here, Hildibald was instead concerned with the comital rights, which were directly or indirectly held by the Salian Otto of Worms, the bishop's rival. ${ }^{24} \mathrm{~A}$ charter supposedly issued by King Louis the German therefore includes the king's concession under the protection of immunity that no king, count or public judge should dare to hear cases, force serfs or freemen of that church to attend a court, or do anything unpleasant in the property and places that belonged to Wimpfen. ${ }^{25}$ This immunity pertained to an entire district that is carefully delineated following the run of rivers and streams, even mentioning specific trees. Outside of this area, the immunity was to be valid for all places where the church of Wimpfen had property, even if it was no more than two or three hides in a village, even outside the diocese of Worms.

This is quite far-reaching. Not only does this charter attempt to remove about a quarter of the Elsenzgau from the count's power in the delineated territory, a strip of land of about ten by twenty kilometres, but also in several places outside of this area. This is much more than any Carolingian king would genuinely have granted to a church, and it shows how keen Hildibald was to curb the Salians' power. It also reflects the trend of Hildibald's own time, in which it had become common to grant immunities that extended beyond the property of the churches (so called sban immunities) ${ }^{26}{ }^{2}$ However, these were usually restricted to the episcopal cities, as Hildibald and HB, involved in the inner workings of the Ottonian chancellery, knew very well.

22 Die Urkunden Ludwigs des Frommen 282, ed. Kölzer, 702-704.

23 Die Urkunden Ludwigs des Deutschen 74a, ed. Kehr, 105-108. The rulings about tolls contained in the charters of Louis the German, Louis the Pious and Pippin are reiterated in Die Urkunden Arnolfs 166, ed. Kehr, 253-254 (one of Hildibald's forgeries), and possibly authentic Die Urkunden Ottos I. 84, ed. Sickel, 165. Lechner, Die älteren Königsurkunden (esp. 531, 547) remains vague on the topic of the authenticity of the latter charter (which is presented as authentic in the MGH edition, although it only exists in a copy by Hildibald's scribe HB); it does not include the interpolation added by Hildibald in Louis the Pious' authentic charter (Die Urkunden Ludwigs des Frommen 282, ed. Kölzer, 702-704) about the tolls in Ladenburg and Wimpfen. This does not mean, however, that Otto's charter 84 from 947, is necessarily authentic, since it could have been created by Hildibald and HB before they interpolated Louis' charter. In reality, the church of Worms did not receive all the tolls in the city until 979 (Die Urkunden Ottos II. 199, ed. Sickel, 225-226, renewed by Otto III in Die Urkunden Ottos III., 12, ed. Sickel, 408-409), when Otto II granted the church of Worms the missing third of the tolls which up to then had been held by the Salian Otto, but pertained to the fisc (Zotz, Adelsherrschaften am Mittelrhein um 1000, 349-350). The authentic charters do not mention Wimpfen and Ladenburg.

24 Bönnen, Bistum und das Hochstift Worms, 18-19.

25 (...) sub integra emunitatis tuitione donavimus atque concessimus, ut nullus noster aut successorum nostrorum comes aut aliquis publicus iudex in rebus aut locis ad Winphinam aspicientibus, que certis nominibus et signis subnotantur, nec ad causas audiendo nec homines ipsius ecclesie tam ingenuos quam et servientes distringendo placitum vel aliquod incommodum audeat facere (Die Urkunden Ludwigs des Deutschen 179, ed. Kehr, 257-258; repeated in Die Urkunden Arnolfs 192, ed. Kehr, 296-298).

26 Stengel, Diplomatik der deutschen Immunitätsprivilegien, 589-594, see for example Die Urkunden Ottos II. 267, ed. Sickel, 310-311 for Strasbourg; Die Urkunden Ottos I. 379, ed. Sickel, 520-521, for Speyer. 
Taken together, what were the results of these forgeries created by the king's chancellor Hildibald and his scribe HB? Hildibald's forgeries concerning immunities went beyond what was normal in the context of the late tenth century, especially in the case of the Elsenzgau, but not by very much. Lechner summarized the results of Hildibald's forgeries as follows: "In short: the rights of the fisc and the power of the count end where the property of Worms begins. ${ }^{27}$ This is exactly what the forgeries tell us, in a strict legal sense. This is, however, what a full tenth-century immunity was all about in any case, and the church of Worms had received such an immunity from Emperor Otto I in 965, still preserved in the original today. ${ }^{28}$ It contains a very general immunity clause prohibiting any action by public or other judges and the collections of dues by royal agents in the possession of the church of Worms and those of Wimpfen and Ladenburg. Otto's charter was itself based on a forgery, a diploma supposedly granted to the church of Worms by Louis the Pious in 814, possibly created in preparation for procuring a new charter from Otto I by one of Hildibald's predecessors. ${ }^{29}$ As a consequence, the church of Worms enjoyed a far reaching immunity over its property including high justice and a control of all dues collected - before Hildibald came into office in 978. The terms of this authentic immunity charter conform exactly to Lechner's statement about Hildibald's forgeries.

So why did Hildibald create all these elaborate forgeries? A first answer to this question is that Hildibald's forgeries attempted to do more than exclude the count and the collection of fiscal dues from the property of the church of Worms: its property was increased in the Lobdengau as well as in the city of Worms, and the reach of its immunity was extended beyond the property of the church of Worms in the Elsenzgau - the latter, including immunity rights over entire villages in which Worms had property, even if it was no more than one or two mansi, is in fact the only truly unusual clause contained in the forgeries. ${ }^{30}$

However, most of the other clauses in the forgeries did little more than specify and support the rulings contained in authentic charters. The fact that Bishop Hildibald thought it necessary to specify the clauses of immunity - by defining borders in the Odenwald and the Elsenzgau, by specifying tolls and by giving the rulings historical depth by projecting them back into the past - shows that general immunity clauses as they were used in Otto I's authentic privilege were not sufficient. Although this privilege in theory prohibited all infringements on the property of Worms by the Salian Duke Otto and his followers, who held most of the comital rights in the diocese, Hildibald thought it necessary to provide very specific boundaries to the count's powers. On the whole what seems to have mattered were explications and support (and some expansion) of the very general immunity granted in authentic charters. All of this is especially evident in the descriptions of specific borders of property

27 »Kurz: Das Recht des Fiskus und die Gewalt des Grafen hört dort auf, wo Wormser Besitz anfängt« (Lechner, Die ältesten Königsurkunden, 384).

28 Die Urkunden Ottos I, 310, ed. Sickel, 424-425. It is a little hard to tell what the terms of the immunity of the church of Worms were before that, since the other immunity charters dating before this were either interpolated or forged. The possibly authentic charter Die Urkunden Ottos I. 84, ed. Sickel, 165, is described as a rban immunity< by Stengel, Diplomatik der deutschen Immunitätsprivilegien (index), but it does not use the word emunitas and only refers to the royal tolls within the city of Worms which were given to the church of Worms (Die Urkunden Pippins 20, ed. Mühlbacher, 28-29).

29 Die Urkunden Ludwigs des Frommen 25, ed. Kölzer, 65-68. This document was long taken to be authentic, but is now seen as a forgery produced at some point before Otto's charter.

30 (Die Urkunden Ludwigs des Deutschen 179, ed. Kehr, 257-258; Die Urkunden Arnolfs 192, ed. Kehr, 296-298). 
and immunity in the Odenwald and the Elsenzgau. ${ }^{31}$ It also indicates that the sacral dimension of immunities, marking out a church and its space as special and holy, was not at the centre of Hildibald's mind when he created his forgeries. The emphasis on spelling out the implications of the immunity so evident in Hildibald's forgeries shows that the chancellorbishop's interests focused on the practical side of immunities: on dues and tolls, on the administration of justice and the exclusion of public officials, especially of counts.

\section{Consequences of immunity}

This leads directly into my second question about the practical consequences of immunities. Or, to put it differently: Were Hildibald's forgeries successful? For assessing this, we have to take a close look at the period of Hildibald's successor, Bishop Burchard of Worms, since there is no evidence for Hildibald's own period. Burchard's tenure, beginning exactly at the turn of the millennium, was marked by fundamental changes in the political order in and around Worms which were accompanied by violence and unrest.

The changes to the political order were due to Burchard's close collaboration with King Henry II (1002-1024). The bishop had been a strong supporter of Henry's election and an ally in the king's successful attempt to found a new diocese in Bamberg, which is why he received several grants from the king. ${ }^{32}$ Already in 1002, the Salians gave up their castle in Worms in return for generous compensation given by the king. Burchard immediately had the castle destroyed and built a collegiate church there. ${ }^{33}$ In 1011, Burchard received the counties of Lobdengau and its eastern neighbour, the county of Wingartheiba, from the king. Interestingly, we find no allusions to Hildibald's forgeries in the charters documenting these acts. ${ }^{34}$ This only started in 1012, when the conflict between Worms and Lorsch about forest rights in the Odenwald flared up again, after Henry had given a forest in the Odenwald to the monastery of Lorsch in May 1012, which overlapped the region that Hildibald had claimed as part of the property of Worms. ${ }^{35}$ In August of 1012, the king ruled largely in favour of Worms, and the charter issued by the king quoted long passages from at least one of Hildibald's forgeries. $^{36}$

31 Ibid. and Die Urkunden der Merowinger 1, 30, ed. Kölzer, 81-84.

32 The bishop was the recipient of the king's earliest transmitted charter and several others: Die Urkunden Heinrichs II. 1, 11, 20, 21, 92, 128, 176, 226, 227, 247, 319, 393, 501 (for the cathedral chapter) ed. Bresslau and Bloch, 1-2, 13, 23-24, 24-25, 115-116, 154-155, 210, 262, 263, 284-285, 399-400, 505-506, 639-641.

33 Die Urkunden Heinrichs II. 20, ed. Bresslau and Bloch, 23-24.

34 Paradoxically, receiving counties and immunities - which meant exemption from public justice and dues exercised and collected mostly by counts - were functionally equivalent, because comital rights and powers ended up in the hands of the bishops either way. Reuter, "Imperial Church System«, 362, and Hoffmann, Grafschaften in Bischofshand, 376, point out that most counties that were given to bishops were administered by lay noblemen who held their office from the bishops. This further supports the notion of similarities, since legal matters within the immunities were also handled by noblemen acting as advocates there. See on the counties given to Worms Hoffmann, Grafschaften in Bischofshand, 449-451.

35 Huffschmid, Ostgrenze des Lobdengaues im Odenwalde.

36 Die Urkunden Heinrichs II. 247, ed. Bresslau and Bloch, 284-285; see Bresslau, Erläuterungen zu den Diplomen Heinrichs II., 184-186. 
The second use of Hildibald's forgeries occurred two years later, and here the immunity of the church of Worms was in play. In 1014, Bishop Burchard complained to the king that certain counts were routinely taking 60 solidi from members of the Worms familia who had been found guilty of wrongdoings of any kind. ${ }^{37}$ This was indeed a breach of the rulings of immunity of the church of Worms, both authentic and forged, since a secular judge was imposing fines on those who belonged to the church of Worms. The charter in which Emperor Henry II ruled that this practice was illegal includes phrases clearly taken from Hildibald's forgeries. Apparently, those forgeries were now accepted as a reasonable basis for new privileges granted by the king. ${ }^{38}$ No specific count is mentioned, but it seems reasonable that the Salian Konrad, grandson of Duke Otto and future King Konrad II, and the sub-counts he appointed, were meant here. ${ }^{39}$ Since the counties of the Lobdengau and its eastern neighbour, the Wingartheiba, were now held by Bishop Burchard himself, he probably was not concerned with abuses there, but with events in and around Worms in the counties that were held by Konrad's family. Perhaps the succession of the young Konrad had created an opportunity for Bishop Burchard to curb the Salians' ambitions.

Returning to the question as to how far Bishop Hildibald's forgeries and interpolations were successful, we may conclude that with regard to immunities their success was ambiguous: the immunity was routinely ignored in spite of them, but his forgeries also offered the wording and the ruling - one could say the semantic resources - to counter these breaches and to create new legal documents.

We learn more about the administration of justice in Worms and the territories of its episcopal church during the period of unrest after 1014 from two documents that were created toward the end of Henry's reign in the early 1020s: the king's intervention in the ongoing conflict between Worms and Lorsch, and Burchard's Lex familiae Wormatiensis ecclesiae; quite probably both documents were related. In 1022, the king issued a charter ordering the advocates of both Worms and Lorsch to punish all members of their respective familiae for attacking members of the other familia - the charter mentions innumerable killings. The king imposed harsh penalties, including branding and beatings for offenders; the advocates, the bishop of Worms and the abbot of Lorsch, were threatened with high fines should they ignore the king's ruling. ${ }^{40}$

Apparently, killings were not restricted to members of the other familia, but also happened within the familia of Worms. This is at least what the Lex Wormatiensis familiae tells us, written by Burchard and issued probably in the same period. In it, Burchard mentions that there had been 35 homicides among the men of the church of Worms in one year. ${ }^{41}$ While including harsh punishments similar to those in the king's decree from 1022, many of the Lex's 32 chapters also treat questions of inheritance and marriage, not of violence, showing that Burchard's aims went further than merely an ad-hoc means of curbing violence during a crisis - as was to be expected from someone who had recently created an authoritative

37 Die Urkunden Heinrichs II. 319, ed. Bresslau and Bloch, 399-400. It contains phrases from Hildibald's forgeries or interpolations attributed to Pippin (20), Louis the German (74b) and Otto I (392).

38 The charter was probably written by a cleric from Worms.

39 Zotz, Adelsherrschaften am Mittelrhein um 1000, 353-354.

40 Die Urkunden Heinrichs II., 501, ed. Bresslau and Bloch, 639-641.

41 Lex familiae Wormatiensis ecclesiae, c.30, ed. Weiland 644. The last comprehensive study of the text is Schulz, Wormser Hofrecht; see also Austin, Vengeance and Law, Jégou, L'évêque, juge de paix, 360-362. 
twenty-volume collection of canon law. Here was someone aiming at really taking the legal matters of his familia into his hands. And, Burchard was doing even more than that: at least three of the chapters addressed all the citizens of Worms - regardless of their legal status. ${ }^{42}$ The extension of the immunity over the entire city and all the people living in it is reflected by these clauses. ${ }^{43}$

Burchard's actions and Henry's charters clearly show that immunities were not just about gaining additional income by taking over what was owed to fisc and its agents and/or the counts. Orderly legal procedures, and the administration of justice mattered, too, otherwise Burchard would not have created new laws.

The evidence also shows, however, that the situation around Worms in the first quarter of the eleventh century was unstable. We do not know the exact causes of this. Was it the ongoing, unresolved conflicts between the episcopal church, Lorsch and the Salian Duke Konrad that caused the troubles? Or was the alteration of the balance of power - brought on by Henry II's actions in the region in favour of his allies Bishop Burchard and the monastery of Lorsch - their most important cause? Probably both factors were important. They were, of course, interconnected in several ways, but I would like to stress the second reason more than has been done in research up to now. The changes in the regional power structure happened because both Bishop Hildibald and his successor Burchard were well placed to receive favours from the kings and emperors, who in return relied on their support. And it is remarkable that we find the most evidence of violence after the Salians had been all but removed from their power in and around Worms and after the king had ruled in favour of Worms in the conflict with Lorsch about forest rights in the Odenwald, directly quoting one of Hildibald's forgeries. Other counties had even entirely passed into the hand of the bishop.

To summarise, most of the goals that Hildibald had set for his church in the charters he created - territorial expansion, independence vis-à-vis the counts, more income from public dues - were achieved by Bishop Burchard. But they came at a price, at least in the immediate aftermath of the changes: unrest, instability and violence in the areas now controlled by the bishop to a larger degree than ever before - mostly by way of immunities.

\section{Conclusion}

This brings me to a short conclusion. At the beginning of this article, I asked two questions: What did institutions expect from receiving immunities? And: can we tell whether they had consequences in practice? Regarding the first question, Bishop Hildibald of Worms wanted to achieve several things through his forgeries, and all of them - not surprisingly - aimed at strengthening his episcopal church in its regional context. Immunity was one of the tools that could be applied to gain an advantage for one's own institution. And it was a powerful tool, too: Hildibald's charters about immunities were one important starting point in the redrawing of regional power structures in favour of the church of Worms in the early eleventh century during the tenure of Bishop Burchard. In this context it is quite remarkable that, as mentioned above, one of the main aims of Hildibald's forgeries was the specification of the terms of immunity, especially its borders - something that fits well with attempting to create a territorial lordship.

42 Lex familiae Wormatiensis ecclesiae, c.26-28, ed. Weiland, 643.

43 It is interesting to note that Burchard might have invited Jews to settle in his city at this time, another group over which bishops usually exercised authority in the eleventh century (Haverkamp, Jews in the Medieval German Kingdom, 14-15). 
Hildibald was also concerned with income from public dues of different kinds and of course with landholdings. But it is important to keep in mind that several of his charters did not simply try to expand the rights of his church - although this also happened, as for example in Wimpfen - but attempted to delineate or specify the very general rulings contained in grants of authentic immunities. This clearly shows that from the perspective of the church receiving an immunity, marking it out as a special, holy place, while certainly important, was not the only objective.

As for the second question about the practical consequences of immunity, it is hard to measure the immediate success of Hildibald's forgeries, since we do not have any other sources that tell us if and how the rulings found in the forged charters were put into practice. Of course, creating documents was not enough to change the world - this also required political opportunity. That opportunity presented itself with the close ties between Emperor Henry II and Bishop Burchard only a few years after Hildibald's death; and Bishop Burchard used his political standing and acumen to achieve a large degree of independence from the regional political powers, thus reaching most of the goals that Hildibald had also tried to achieve on parchment a few years earlier. Here, it becomes clear that immunities mattered and had consequences on the ground. The counts' powers were severely limited in and around Worms, and judicial matters lay in the hand of the bishop and his advocates (about whom we know very little).

The power of immunity is also demonstrated by the fact that its application in practice after the expulsion of the counts was probably a major factor in the wave of violence that afflicted Worms in the second half of Burchard's episcopate in the early eleventh century. Of course we might assume that the reports of violence are exaggerated, but in any case there seem to have been problems in the administration of justice, and Burchard obviously felt it necessary to create new legal rulings.

This also shows that it was not only exactions of judicial fees or the dues that mattered, but that more was in play: the administration of justice and the power that came with it. One probably should not generalize too much from Burchard's example, because he was by all standards an exceptional figure. But in the light of the evidence presented here, it seems quite likely that the exercise of justice - and the power that came with it - was a central issue for churches striving for immunities, counties and other rights in the Latin West around the year 1000.

One final point: This paper has avoided taking a royal perspective on granting immunities, but the results presented here have obvious implications for this field too. When Henry II (and his predecessors) granted far-reaching immunities to the church of Worms or accepted those that were presented to him, they were exercising royal power. The dispensation and control of immunities was a powerful means that allowed kings to profoundly change local power structures. 


\section{References}

Austin, Greta G., Shaping Church Law around the Year 10oo: The Decretum of Burchard of Worms (Aldershot, 2009).

Austin, Greta, Vengeance and Law in Eleventh-Century Worms: Burchard and the Canon Law of Feuds, in: Wolfgang P. Müller and Mary J. Sommar (eds.), Medieval Church Law and the Origins of the Western Legal Tradition: A Tribute to Kenneth Pennington (Washington, 2006) 66-76.

Bachrach, David S., The Histories of a Medieval German City, Worms c. 1000-c. 1300. Translation and Commentary (Farnham, Surrey 2014).

Bachrach, David S., Immunities as Tools of Royal Military Policy unter the Carolingian and Ottonian Kings, Zeitschrift der Savigny-Stiftung für Rechtsgeschichte, Germanistische Abteilung 130 (2013) 1-36.

Bönnen, Gerold, Die Blütezeit des hohen Mittelalters: von Bischof Burchard bis zum Rheinischen Bund (1000-1254), in: Gerold Bönnen (ed.), Geschichte der Stadt Worms (2nd edition) (Darmstadt, 2015) 133-179.

Bönnen, Gerold, Das Bistum und das Hochstift Worms und der Neckarraum im hohen Mittelalter, in: Christian Burkhart (ed.), Die Grafen von Lauffen am mittleren und unteren Neckar (Heidelberg, 2016) 9-25.

Bresslau, Harry, Erläuterungen zu den Diplomen Heinrichs II., Neues Archiv der Gesellschaft für ältere deutsche Geschichtskunde 22 (1897) 137-221.

Brunner, Heinrich, Deutsche Rechtsgeschichte, vol. 2 (2nd edition revised by Claudius Freiherr von Schwerin) (Munich, 1928).

Bührer-Thierry, Geneviève and Jégou, Laurent, Construction des pouvoirs et formation des espaces sacrés: le paradoxe de l'immunité. Autour de Negotiating Space, Bulletin du centre d'études médiévales d'Auxerre / BUCEMA, Hors-série 5 (2013). Retrieved 13 February 2017: http://cem.revues.org/12537.

Burchard of Worms, Lex familiae Wormatiensis ecclesiae, ed. Ludwig Weiland, MGH Const 1, (Hannover, 1893) 640-644.

Codex Laureshamensis 1, ed. Karl Glöckner, Darmstadt 1929.

Haarländer, Stephanie, Die Vita Burchardi im Rahmen der Bischofsviten seiner Zeit, in: Wilfried Hartmann (ed.), Bischof Burchard von Worms, 1000-1025 (Mainz, 2000), 19-60.

Haverkamp, Alfred, Jews in the Medieval German Kingdom, trans. from German by Christoph Cluse (Trier, 2005).

Hartmann, Wilfried (ed.), Bischof Burchard von Worms, 1000-1025 (Mainz, 2000).

Hoffmann, Hartmut, Grafschaften in Bischofshand, Deutsches Archiv für Erforschung des Mittelalters 46 (1990) 375-480.

Huffschmid, Maximilian, Die Ostgrenze des Lobdengaues im Odenwalde, Zeitschrift für die Geschichte des Oberrheins 45 (1891) 105-118.

Jégou, Laurent, L'évêque, juge de paix. L'autorité épiscopale et le règlement des conflits entre Loire et Elbe (milieu VIIIe-milieu XIe siècle) (Turnhout, 2011).

Kohl, Thomas and Felten, Franz J., Worms - Stadt und Region im frühen Mittelalter von 600-1000, in: Gerold Bönnen (ed.), Geschichte der Stadt Worms (2nd edition), (Darmstadt, 2015), 102-132.

Lechner, Johann, Die älteren Königsurkunden für das Bistum Worms und die Begründung der bischöflichen Fürstenmacht, Mitteilungen des Instituts für Österreichische Geschichtsforschung 22 (1901) 361-419 and 529-574. 
Murray, Alexander C., Immunity, Nobility and the Edict of Paris, Speculum. A Journal of Medieval Studies 69/1 (1994) 18-39.

Reuter, Timothy, The "Imperial Church System " of the Ottonian and Salian Rulers: A Reconsideration, Journal of Ecclesial History 33 (1982) 347-374.

Rosenwein, Barbara, Negotiating Space. Power, Restraint, and Privileges of Immunity in Early Medieval Europe (Ithaca, 1998).

Schulz, Knut, Das Wormser Hofrecht, in: Wilfried Hartmann (ed.), Bischof Burchard von Worms, 1000-1025 (Mainz, 2000) 251-278.

Schulz, Knut, Denn sie lieben die Freiheit so sehr. Kommunale Aufstände und die Entstehung des europäischen Bürgertums im Hochmittelalter (Darmstadt, 1992).

Stengel, Edmund E., Diplomatik der deutschen Immunitätsprivilegien vom 9. bis zum Ende des 11. Jahrhunderts (Innsbruck, 1910).

Die Urkunden der Merowinger, ed. Theo Kölzer, MGH DD (Hannover, 2001).

Die Urkunde Pippins, Karlmanns, Karls des Großen, ed. Engelbert Mühlbacher, MGH DD (Hannover, 1906).

Die Urkunden Ludwigs des Frommen, ed. Theo Kölzer, MGH DD (Wiesbaden, 2016).

Die Urkunden Ludwigs des Deutschen, Karlmanns und Ludwigs des Jüngeren, ed. Paul Kehr, MGH DD (Berlin, 1934).

Die Urkunden Arnolfs, ed. Paul Kehr, MGH DD (Berlin, 1940).

Die Urkunden Konrad I., Heinrich I. und Otto I., ed. Theodor Sickel MGH DD (Hannover 18791884).

Die Urkunden Ottos des II., ed. Theodor Sickel, MGH DD (Hannover, 1888).

Die Urkunden Ottos des III., ed. Theodor Sickel, MGH DD (Hannover, 1893).

Die Urkunden Heinrichs II. und Arduins, ed. Harry Bresslau and Hermann Bloch MGH DD (Hannover, 1900-1903).

Weinfurter, Stefan, Das Jahrhundert der Salier 1024-1125 (Ostfildern, 2008).

Zotz, Thomas, Bischöfliche Herrschaft, Adel, Ministerialität und Bürgertum in Stadt und Bistum Worms (11.-14- Jahrhundert), in: Josef Fleckenstein (ed.), Herrschaft und Stand. Untersuchungen zur Sozialgeschichte im 13. Jahrhundert (Göttingen, 1977) 92-136.

Zotz, Thomas, Adelsherrschaften am Mittelrhein um 1000, in: Wilfried Hartmann (ed.), Bischof Burchard von Worms, 1000-1025 (Mainz, 2000) 349-369. 